\author{
Aurimas Švedas \\ Uniwersytet Wileński \\ Wilno \\ aurimas.svedas@if.vu.lt
}

\title{
Formy dialogu pamięci i historii w humanistyce litewskiej po roku 1990 (wykorzystanie metody oral history)
}

Przedmiotem niniejszego artykułu jest ukształtowana w litewskiej humanistyce niepodległej Republiki Litewskiej tradycja badań z wykorzystaniem metody historii mówionej (ang. oral history). Podczas pisania tego artykułu poszukiwano odpowiedzi na następujące pytania: w jaki sposób na przełomie XX i XXI wieku litewscy humaniści wykorzystują metodę badawczą oral history oraz wobec jakich wyzwań stają? Jakie zagadnienia badawcze były, są i będą rozwiązane w najbliższej przyszłości dzięki wykorzystaniu tej metody? ${ }^{1}$ Jakie teksty wykorzystujące metodę oral history należy uznać za najważniejsze i o największym potencjale w kontekście procesów zachodzących w litewskiej humanistyce? Artykuł składa się z dwóch części. W pierwszej omówiono różnego rodzaju wyzwania, przed którymi stają badacze litewscy wykorzystujący oral history jako główne narzędzie badawcze. W drugiej części tekstu skupiono się na prezentacji i omówieniu konkretnych przykładów zakończonych sukcesem badań

1 Za inspirację tego tekstu można uważać sfromułowane przed kilkoma laty w recenzji Pokalbiai kaip patirčių atverties ir prasmių kūrimo laukas (Švedas, 2015, ss. 190-196) pytania, do których autor teraz powraca.

This is an Open Access article distributed under the terms of the Creative Commons Attribution 3.0 PL License (creativecommons.org/licenses/by/3.0/pl/), which permits redistribution, commercial and non-commercial, provided that the article is properly cited. (C) The Author(s) 2018. (c) To Polish translation: Tomasz Błaszczak \& Małgorzata Kasner 2018.

Publisher: Institute of Slavic Studies, Polish Academy of Sciences

[Wydawca: Instytut Slawistyki Polskiej Akademii Nauk] 
z wykorzystaniem metody wywiadu ${ }^{2}$ oraz sposobów rozwiązywania pojawiających się problemów. W artykule oparto się na metodzie historiograficznej, przeanalizowano konkretne przykłady $\mathrm{z}$ historiografii litewskiej, zastosowano dostępne metody analityczne i syntetyczne.

\section{Wyzwania, z którymi mierzą się naukowcy planujący wykorzystanie w swoich badaniach metody oral history}

W zachodnioeuropejskiej historiografii droga oral history - od nietypowego badania historii i sposobu opisu do uznanej powszechnie i popularnej metody - była dość długa. W drugiej połowie XX wieku w naukach historycznych (i ogólnie humanistycznych) zostały zidentyfikowane cztery, następujące po sobie, paradygmaty oral history: 1) powojenna fala zainteresowania pamięcią jako źródłem „historii człowieka”; 2) intensywne dążenie w latach 80. ubiegłego wieku do stosowania w badaniach nad pamięcią podejścia postpozytywistycznego; 3) radykalne przemiany w latach 90. $\mathrm{XX}$ wieku dotyczące reinterpretacji roli badacza zajmującego się historią mówioną jako przeprowadzającego i analizującego wywiady; 4) wywołane u progu XXI wieku przez rewolucję cyfrową zmiany w badaniach oral history ${ }^{3}$.

Dwudziestowieczna humanistyka litewska nie doświadczyła powyższych zmian. Dopiero na początku XXI wieku oral history znalazła się w kręgu zainteresowań niewielkiej grupy naukowców litewskich i to przede wszystkim jako zmiana jakościowa w dostępie do nowych tematów i unikatowych źródeł informacji. Warto zaznaczyć, że w XX wieku - w okresie międzywojennym i okresie Litwy Sowieckiej, coś na podobieństwo metody oral history wykorzystywano w badaniach terenowych, podczas których badacze gromadzili informacje o konkretnych mieszkańcach kraju, gospodarstwie, codziennym życiu, historii i zwyczajach. Z dużym prawdopodobieństwem można stwierdzić, że w akademickim środowisku humanistycznym był wykorzystywany tylko jeden rodzaj wywiadu - etnograficzny, który z oral history praktycznie nie miał nic wspólnego 4 .

${ }^{2}$ Wywiadu otwartego, o elastycznej strukturze (przyp. tłum.).

3 Więcej zob. Thomson, 2007. Dążąc do uzyskania szerszego oglądu problematyki rozwoju oral history, należałoby także sięgnąć po inny tekst tego autora: Thomson, 1998.

4 „Kwestionariusz etnograficzny” - konkretny, rygorystycznie przestrzegany zestaw pytań, który w XX wieku był wykorzystywany do zbierania danych etnograficznych i folklorystycznych. Należy w tym miejscu zaznaczyć, że pod tym pojęciem kryje się stosowana przez etnografów i badaczy folkloru metoda ściśle ustrukturyzowanego wywiadu. Ta strategia była związana z tym, że w litewskiej społeczności akademickiej praktycznie przez cały wiek XX wywiad był postrzegany jako narzędzie warsztatu dziennikarskiego, a co za tym idzie, naukowiec nie powinien $\mathrm{z}$ tego nieodpowiedniego instrumentarium korzystać. 
Stało się już regułą, że metoda oral history jest dziś powszechnie wykorzystywana przez litewskich humanistów podczas zbierania informacji o różnych wydarzeniach, procesach i osobach z czasów Litwy Sowieckiej i wczesnej Litwy postsowieckiej. Najczęściej stosują ją doktoranci przygotowujący rozprawy na wyżej wymienione tematy ${ }^{5}$.Zazwyczaj pamięć staje się obiektem badań w momencie, gdy badacz spotyka się z niedostatkiem dokumentów archiwalnych i chce uzyskać unikatową - w sensie jakościowym, niezanotowaną w żadnych innych źródłach informację.

Metoda wywiadu pozwala jednak nie tylko w nowy sposób zdobywać fakty o przeszłości, ale również daje możliwość jej przemyślenia, przeżycia oraz nadania sensu, gdy badacz i jego rozmówca jednoczą wysiłki, by przekroczyć granice pytania: jak było naprawdę, i oddać się autorefleksji na temat: co o tym aktualnie myślimy i jakie znaczenie dla nas, żyjących tu i teraz, zyskuje przeszłość, proces jej od(tworzenia) i rezultat tego procesu - nowa opowieść. Niestety, jak dotąd litewscy humaniści nie poddali szerszej refleksji nowych możliwości poznania historii i pamięci, choć mocne i słabe strony oral history coraz częściej są tematem krytycznej analizy w różnych artykułach, recenzjach i dyskusjach (zob. Švedas, 2010; Vaiseta, 2012). Kierunek myślenia ich autorów wyznaczają autentyczne, osobiste doświadczenie badacza oraz poglądy wyrażone w historiografii zachodnioeuropejskiej, która już dokładnie przeanalizowała potencjał i ograniczenia metody wywiadu.

Na przełomie XX i XXI wieku litewscy humaniści, wykorzystujący w swoich badaniach metodę wywiadu, zderzyli się z kilkoma wyzwaniami.

Pierwsze z nich to wyścig z czasem. Zdolność społeczeństwa oraz naukowców do słuchania, rejestrowania oraz zachowania relacji najczęściej przedstawicieli starszego pokolenia, które są potrzebne społeczeństwu postsowieckiemu do odbudowy uszkodzonych w okresie sowieckim form pamięci komunikacyjnej, stanowi poważny problem ${ }^{6}$. Oczywiście, z podobnymi wyzwaniami muszą się mierzyć także zagraniczni naukowcy, korzystający z tej metody, jednak w społeczeństwach postsowieckich ten wyścig utrudnia ambiwalentny stosunek do tego okresu historycznego, do osoby go

${ }^{5}$ Wymieńmy w tym miejscu kilka prac doktorskich, których autorzy wykorzystali metodę wywiadu jako ważny punkt odniesienia i przeciwwagę dla przeprowadzanych badań: Saulius Grybkauskas (2007), Pramonés valdymas sovietinéje Lietuvoje 1965-1985 m.: ittampos ir konfliktai; Vilius Ivanauskas (2008), Lietuviškoji nomenklatūra biurokratinèje sistemoje: tarp stagnacijos ir dinamikos (1970-1988); Valdemaras Klumbys (2009), Lietuvos kultūrinio elito elgsenos modeliai sovietmečiu; Aurimas Šukys (2012), Intelektualu alternatyvi veikla sovietu Lietuvoje 1956-1988; Ūla Tornau (2016), Oficialieji ir kasdieniai sovietinio Vilniaus erdvés naratyvai: Lukiškiu mokslo kvartalas; Mingailè Jurkutė (2016), Lietuvos partizany karo atmintis: sovietinis, vietinis ir išeivijos pasakojimai.

${ }^{6}$ Jak pokazała w swoich badaniach Dobrochna Kałwa, rozwijana w społeczeństwach postkomunistycznych tradycja oral history jest skierowana przede wszystkim na odtworzenie pamięci zbiorowej. Więcej zob. Kałwa, 2010. 
odtwarzającej, analizującej i interpretującej. I jest to problem zarówno dla badaczy, jak i ich informatorów.

Przez długi czas niechęć do rozmowy o czasach Litwy Sowieckiej, do dzielenia się świadectwami i wspomnieniami tej epoki, wynikała z kilku wzajemnie sprzężonych przyczyn: 1) obawy przed zbytnią otwartością i strachu przed powrotem sowieckiej przeszłości: A może to wszystko jeszcze powróci?; 2) dążenia humanistów (historyków) do zlikwidowania białych plan przede wszystkim poprzez dostęp do nowego materiału archiwalnego; 3) ogólnospołecznej obojętności wobec rozmowy jako przestrzeni ujawniającej doświadczenie i nadającej mu znaczenie (to zjawisko staje się szczególnie widoczne, gdy porównamy sytuację w Polsce i przyjrzymy się popularnemu, osadzonemu w silnej i długiej tradycji gatunkowi „wywiadu rzeki”); 4) zmiany, panującego w pierwszym dziesięcioleciu niepodległości konsensusu: jeszcze za wcześnie o tym mówić, na zaczynające powoli dominować w XXI wieku: a może po prostu zapomnijmy o całym tym absurdzie i żyjmy dalej.

Wymienione wyżej przyczyny zadecydowały o tym, że w latach 90 . XX wieku, w okresie odbudowy litewskiej niepodległości, pokolenie ówczesnych sześćdziesięciolatków nie opowiedziało historii swojego życia i nie zostało przez nikogo wysłuchane. W trochę lepszej sytuacji znaleźli się żyjący w okresie przemian pięćdziesięcioletni przedstawiciele elit politycznych, akademickich i kulturalnych, których opowieści biograficzne oraz (auto)refleksje w większości przypadków zostały utrwalone. Z drugiej strony, przedstawiciele nauk humanistycznych, korzystający z metody wywiadu jako narzędzia poznania przeszłości, na razie nie pracują zbyt intensywnie z określaną jako „milcząca większość” (termin rosyjskiego mediewisty Arona Guriewicza) częścią społeczeństwa.

Można prognozować, że w najbliższym czasie przedstawiciele nauk humanistycznych i społecznych, podejmujący próbę zbadania i przedstawienia epoki niepodległej Litwy, zderzą się z analogicznym - wynikającym z upływającego czasu - wyzwaniem. Jak na razie jest to sfera działań publicystów, eseistów, prozaików ${ }^{7}$, choć coraz częściej słyszy się ponaglenia, żeby zwrócić się w stronę całościowego opisu tego okresu, którego brak społeczeństwo silnie odczuwa ${ }^{8}$.

Drugie wyzwanie to brak refleksji teoretycznej. Apriorycznie negatywny lub pozytywny, przykładający odpowiednią wagę do rozwiązania zagadnień teoretycznych, pogląd na oral history jest kolejnym poważnym wyzwaniem dla litewskiej humanistyki.

${ }^{7}$ Utrwalaniem okresu niepodległej Litwy i refleksjami na ten temat konsekwentnie zajął się prekursor litewskiej eseistyki, poeta i pisarz - Rolandas Rastauskas, a później tak zwana szkoła eseistyczna tygodnika kulturalnego „Šiaurès Atėnai”. W ostatnich czasach litewscy pisarze, patrzący na okres odzyskiwania niepodległości z perspektywy zwykłego człowieka, bliskiej metodzie oral history, napisali powieści, które doczekały się wielkiego odzewu w społeczeństwie: Rimantas Kmita, Pietinia kronikas: popromanas (Kmita, 2016); Kęstutis Šapoka, Pušis, kuri juokès (Šapoka, 2018).

${ }^{8}$ W tym kontekście należy przywołać kulturologa Jurija Dobriakova (2014). 
Jest oczywiste, że tylko dzięki refleksji teoretycznej będzie można zrobić wykraczający poza zbieranie faktów krok naprzód ku bardziej skomplikowanym zadaniom związanym z interpretacją przeszłości i jej odzwierciedleń. Tym samym można będzie rozwiązać również problem uznania przez litewską społeczność akademicką prac naukowych i książek z gatunku oral history. Tę potrzebę odzwierciedla dość regularny brak zrozumienia pomiędzy młodą, średnią i starszą generacją humanistów. Entuzjastyczne deklaracje młodych: „Nasze badania pokazały coś nowego i ciekawego!” są zwykle zbywane przez starszych kolegów machnięciem ręki i stwierdzeniem: „I tak z zasady nie wierzymy w tę metodę i osiągnięte dzięki niej rezultaty".

W takim wypadku należy wymienić kilka niezwykle ważnych naszym zdaniem problemów, do których w najbliższej przyszłości trzeba będzie się odnieść (korzystając z bogatego dorobku i doświadczenia historiografii zachodniej):

1. Wyzwania i nowe możliwości prowadzenia badań przeszłości i teraźniejszości wynikające z wykorzystania metody wywiadu podczas badania specyfiki ludzkiej pamięci (brak ciągłości, porządku, płynność i autorefleksja itp.).

2. Wartość poznawcza informacji uzyskiwanych za pomocą wywiadu to nie tylko szukanie odpowiedzi na pytanie, jak było naprawdę, ale także powstające $\mathrm{w}$ trakcie badań odzwierciedleń przeszłości pytanie o mechanizmy informacji i ich relacje z danymi z innych źródeł (przede wszystkim - dokumentami archiwalnymi).

3. Specyficzne indywidualne i profesjonalne wymagania wobec badacza, który za pomocą metody wywiadu analizuje nie tylko historię, ale także pamięć, która wymaga jakościowo innego przygotowania teoretycznego i metodologicznego, a ponadto takich cech osobistych badacza, jak: empatia, umiejętność wyrażania emocji, umiejętność współpracy.

4. Potrzeba zrozumienia oral history jako specyficznego sposobu badania historii, refleksji i narracji historycznej w kontekście dorobku historiografii drugiej połowy XX wieku (w szczególności wobec wyzwań postmodernizmu i szukania na nie odpowiedzi).

5. Trudności przejścia od metody wywiadu i oral history, dotyczących zazwyczaj skali mikro (jednostka) do skali makro (społeczeństwo), i próby wykorzystania danych uzyskanych podczas wywiadu do tworzenia wspólnych obrazów przeszłości albo do korekty tych już utrwalonych w historiografii oraz pamięci kulturowej.

Nie ma wątpliwości, że w badaniach z wykorzystaniem metody wywiadu, których celem jest stawianie kolejnych pytań i rozwiązywanie nowych - uwzględniających znaczenie i hierarchię zagadnień - litewscy humaniści będą musieli w przyszłości rozstrzygnąć postawione wyżej (a także inne) kwestie o charakterze teoretycznym.

Trzecie wyzwanie to zasady panujące w litewskiej polityce naukowej (wartościowanie i ocena efektu wytworu pracy akademickiej). Panująca przez długi czas na Litwie praktyka oceny wytworów pracy humanistów na zasadzie ratingów była wprost 
zniechęcająca dla osób zajmujących się badaniami oral history. Na przełomie XX i XXI wieku upowszechniła się opinia, że badania z nurtu oral history i ich oceny będą włączane do kategorii popularyzacji nauki, która jako niezbędna forma działalności pojawia się w życiorysie naukowym każdego badacza. Jednak na razie popularyzacja nauki jest oceniana przez litewskich biurokratów akademickich jako „działalność niezbyt poważna".

Ostatnie lata pokazują nowy trend: książki z nurtu oral history coraz częściej trafiają do kategorii publikacji źródeł i w ten sposób umożliwiają zarówno konkretnemu naukowcowi (albo ich grupie), jak i właściwym instytucjom, uznania jako niezbędnych, klasyfikowanych w ratingach wytworów pracy naukowej oraz związanego z nimi (tj. pozycją w ratingu) finansowania'.

Nie ma wątpliwości, że omówione powyżej wyzwania wobec priorytetów, ustanowionych przez litewską politykę naukową (ocena wytworów pracy naukowej), są ściśle powiązane z już analizowaną kwestią braku refleksji teoretycznej i umiejętności prezentowania środowisku akademickiemu i społeczeństwu metody oral history oraz realizowanych dzięki niej badań.

\section{Charakterystyka metody oral history w litewskiej humanistyce}

W ukształtowanej po roku 1990 tradycji badań oral history należy zwrócić uwagę na kilka tekstów, które ukazały jej potencjał, a zarazem odejście od polowania na dane i fakty w kierunku ambitnych badań społecznych oraz konstruowania wspólnych obrazów dziejów społeczeństwa, a także w kierunku intensywniejszej refleksji teoretycznej i metodologicznej. Jednak zanim zostaną omówione badania, ilustrujące potencjał metody oral history w badaniach historii i pamięci, należałoby przedstawić kilka projektów naukowych (zainicjowanych przez litewskich folklorystów i socjologów), których autorzy pracują z innymi formami wywiadu bliskimi oral history. Te z sukcesem zrealizowane projekty, w pewnym sensie, przyczyniły się do

${ }^{9}$ W tym wypadku należy podkreślić, że w ostatnim dziesięcioleciu XX wieku i na początku XXI wieku stosowane na Litwie kryteria wartościowania wytworów pracy akademickiej były dość niekorzystne dla bardzo ważnej z punktu widzenia historyków działalności - prac związanych z przygotowaniem do druku i publikacji źródeł. Taka praktyka, bez wątpienia, dość negatywnie odbiła się nie tylko na badaczach najnowszej historii, którzy korzystają z oral history podczas tworzenia bazy własnych źródeł, ale także na przedstawicielach mediewistyki i historii nowożytnej, którzy pracują z archiwaliami. Istotny przełom w sposobach oceny nastąpił na Litwie w 2009 roku. Właśnie wtedy, po opracowaniu przez ministra oświaty i nauki „Metodyki wartościowania prac naukowych instytucji naukowych i instytucji zajmujących się studiami" (Mokslo ir studijų institucijų mokslo darbų vertinimo metodika), przygotowane przez historyka do druku źródło naukowe (także to powstałe w ramach badań oral history) zaczęto oceniać jak solidną pracę naukową, porównywalną z pracą nad monografią. 
stworzenia przychylnego kontekstu nie tylko dla badań historycznych, ale także innych humanistycznych:

1. Poszukiwanie elementów folklorystycznych we współczesnej tradycji oralnej

Jak już wspomniano wcześniej, przez większą część XX wieku kwestionariusz etnograficzny był chyba jedyną formą wywiadu wykorzystywaną przez litewskich humanistów (przede wszystkim badaczy folkloru i etnografów). Jego ograniczenia jako instrumentu badawczego pojawiły się na przełomie XX i XXI wieku, gdy badania folklorystyczne i etnografia przeszły istotną transformację, podobnie jak inne na polu nauk humanistycznych i społecznych, w których coraz szybciej umacniały się idee, teorie i metody $\mathrm{z}$ dziedziny socjologii oraz antropologii kulturowej.

Reakcją na wymieniowe wyżej tendencje (przejmowanie idei, teorii, metod), a także celem, jakim było rozpoczęcie badań nad współczesnym stanem folkloru, był zainicjowany przez litewskich folklorystów i przedstawicieli pokrewnych dziedzin humanistycznych (przede wszystkim literaturoznawców) projekt: Homo narrans: folklorines atminties tyrimai (Homo narrans: badania pamięci folklorystycznej). Realizowany w latach 2010-2012, po pewnym czasie zaowocował ważną akademicką monografią zbiorową (Aleksynas \& Giliasevičienė, 2012). Głównym obiektem badań prezentowanych w monografii jest snuta przez człowieka opowieść biograficzna (narracja), obejmująca jego przeszłość i teraźniejszość. W ten oto sposób uczyniono bardzo ważny krok od tradycyjnego ludowego narratora do człowieka, który opowiada o swoim świecie i życiu w nim. Ten sposób kontaktu między badaczem a narratorem pozwala mówić o statusie równorzędnego rozmówcy, a nie „dostarczyciela informacji”.

2. Formy pamięci okresu sowieckiego i sposoby ich wyrażania w opowieściach biograficznych

Do rozmówców, którzy zdecydowali się podzielić tym, co dla nich najcenniejsze historiami swojego życia, dotarli badacze (głównie socjolodzy) skupieni wokół projektu naukowego, a później monografii Sovietmečio atmintis gyvenimo istorijose (Pamięć okresu sowieckiego w opowieściach biograficznych) (Žilinskienė, Leinartè, Kraniauskiené, Šutinienė, \& Gečienė, 2014). W monografii przedstawiono analizy 181 opowieści biograficznych, nagranych w latach 2010-2011 na Litwie, w Niemczech, Izraelu i Polsce. Badacze opowieści biograficznych z początku XXI wieku starali się odpowiedzieć na następujące ważne pytania: Jak w narracjach są wspominane, wykorzystywane w czasach Litwy Sowieckiej strategie gromadzenia i dostępu do kapitału 
społecznego (więzi pokrewieństwa, łapówki, blatas $^{10}$, znajomości, układy) oraz do innych zasobów? Jak opowieści odzwierciedlają, istniejące w epoce sowieckiej, przejawy socjalizacji i adaptacji społecznej? Jak i jakie formy nostalgii ukazują wspomnienia byłych mieszkańców Litwy Sowieckiej? Jakie powody decydują o powstawaniu i formach wyrażania nostalgii za czasami sowieckimi?

„Pamięć ludzi żyjących w okresie Litwy Sowieckiej jest ważnym źródłem ciągłości ich tożsamości, a w czasach przemian, zmienności wydarzeń i procesów historycznych także źródłem interpretacji i sensu" - tak brzmi pierwsze zdanie wniosków prezentowanych w omawianej monografii (Žilinskienè i in., 2014, s. 265) ${ }^{11}$. Można je interpretować na dwa sposoby: jako próbę uogólnienia rezultatów poważnego badania i jako bardzo ważny punkt odniesienia dla dalszych studiów. Historycy i inni humaniści, którzy na początku XXI wieku zainicjowali nowe badania historii i pamięci okresu sowieckiego, wykorzystali metodę oral history.

Za najważniejsze przykłady powstałej w litewskiej humanistyce XXI wieku tradycji badań oral history uważa się pięć następujących projektów autorstwa pojedynczych badaczy albo zespołów naukowych:

\section{A. Losy kobiet $\mathrm{i}$ ich przemiany tożsamościowe w epoce sowieckiej}

Jedną z pierwszych badaczek wykorzystujących w swoich badaniach metodę oral history jest historyczka Dalia Marcinkevičienè-Leinartė, która podczas prowadzenia badań nad przemianami tożsamościowymi kobiet (lata 40.-80. XX wieku), opierała się na wywiadach przeprowadzonych przez siebie albo innych historyków. Tematyka rozmów dotyczyła doświadczeń konkretnego okresu Litwy Sowieckiej, a rozmówczyniami były kobiety z różnych grup społecznych. Rezultatem przeprowadzonych badań jest książka, która jako pierwsza w litewskiej historiografii na podstawie analizy biografii kobiet ukazuje wpływ ideologii sowieckiej na stosunki społeczne, próbuje odnaleźć kobiety w tworzonej przez mężczyzn, naznaczonej przemocą historii Litwy Sowieckiej drugiej połowy XX wieku, i rozpoczyna opowieść o kruchości ich losów (Marcinkevičienè, 2007) $^{12}$.

Jak żyły i przeżyły swoje codzienne życie kobiety sowieckie - jak oswoiły sowiecki porząalek, surowy reżim polityczny? Parafrazując słowa B. Ashcrofta: one bez żadnych wymówek „wciskały” swoje życie między dzieła Lenina i czasopismo „Kobieta”, między kołchozowy czyn społeczny, zebrania partyjne i ślub kościelny, między aborcje, utracone na zesłaniu dzieci i tanie kwiaciaste sukienki - wszystko po to, by mogły przeżyć

${ }^{10}$ Lit. blatas (z jęz. rosyjskiego блат) - to powszechnie używane w byłym ZSRR określenie łapówki, dojścia, znajomości (przyp. tłum.).

${ }^{11}$ Przekład cytatów na język polski - tłumacze artykułu T.B. i M.K.

12 Dla czytelnika międzynarodowego przygotowano angielski wariant książki: Adopting and Remembering Soviet Reality: Life Stories of Lithuanian Women, 1945-1970 (Marcinkevičienè, 2010). 
w oswojonym przez siebie życiu codziennym, by były w stanie nakarmić i przytulić tych, co pozostali jeszcze przy życiu - mężów i dzieci.

Tak podsumowuje w swojej recenzji przedstawione w książce historie Rasa Baločkaite (2009). Przywołany fragment tekstu, podobnie jak badania D. Leinartè, nie tylko zaktualizował w litewskim społeczeństwie temat historii, ale także wzbogacił jego pamięć komunikacyjną o historie kobiet i ich doświadczenia w sytuacjach ekstremalnych ${ }^{13}$.

B. Badania więzi społecznych w kontekście zjawiska niedostosowania do modelu sowieckiego

Grupa przedstawicieli nauk społecznych i humanistycznych związana z Instytutem Stosunków Międzynarodowych i Nauk Politycznych Uniwersytetu Wileńskiego w latach 2009-2011 intensywnie wykorzystywała w swoich badaniach nad fenomenem Sąjūdisu ${ }^{14}$ metodę wywiadu. Podczas badań przeprowadzono wywiady ze wszystkimi żyjącymi członkami narodowej grupy inicjatywnej Sąjūdisu oraz z członkami grup regionalnych, ruchu etnokulturowego, podziemia katolickiego, ze środowiskiem muzyków rockowych, artystów i naukowców, aktywistów ruchu ekologicznego i ochrony dziedzictwa (ogółem w czasie badań przeprowadzono ponad 300 wywiadów). Zebrane podczas wywiadów relacje zostały wykorzystane do zilustrowania funkcjonujących wówczas często na granicy legalności, pozornie niewidocznych dla sowieckich struktur represji, sieci wzajemnych powiązań, i w istotny sposób przyczyniły się do zbadania genezy społecznego ruchu Sąūdis ${ }^{15}$. Materiały zostały opracowane zgodnie z metodologią społecznej analizy sieciowej (social network analysis) - metodą nową, a jednak coraz popularniejszą na Litwie.

Nowatorskie badania doczekały się zainteresowania społeczeństwa i środowiska akademickiego. Monografia zbiorowa Sajūdžio ištakų beieškant (W poszukiwaniu początków Sąjūdisu) (Kavaliauskaitè \& Ramonaitė, 2011) była szczegółowo recenzowana ${ }^{16}$ i aktywnie omawiana podczas różnorodnych seminariów i publicz-

${ }^{13}$ Autor nawiązuje w tym miejscu do książki Erica Hobsbawma Wiek skrajności (Hobsbawm, 1999) (przyp. tłum.).

14 Lit. Lietuvos Persitvarkymo Sąjūdis (Litewski Ruch na rzecz Przebudowy).

15 Rezultaty wspomnianych wyżej badań przedstawiono w monografii zbiorowej Sajūdžio ištaku beieškant: nepaklusniųų tinklaveikos galia (Kavaliauskaite \& Ramonaitė, 2011). Ich inicjatorzy na podstawie danych empirycznych, zebranych w drodze wywiadu, badali później zagadnienie istnienia i rozwoju w okresie sowieckim alternatywnego („samodzielnego”) społeczeństwa, opisane w publikacji Nematoma sovietmečio visuomenè (Ramonaitè, 2015). Tę monografię zbiorową uzupełnia publikacja z zakresu historii mówionej Kažkas tokio labai tikro: Nepaklusniosios sovietmečio visuomenés istorijos. Sakytinés istorijos šaltinių rinkinys (Ramonaitè, Kavaliauskaitè, \& Klumbys, 2015).

16 Przede wszytkim należy tu przywołać często cytowane publikacje, które ukazały się na łamach czasopisma „Knygų aidai” (nr 3, 2012) autorstwa Neriji Putinaitė, Nerijusa Šepetysa, Arunasa Streikusa, 
nych dyskusji. Dzięki intensywnej wymianie myśli stawało się jasne, że badania z wykorzystaniem metody wywiadu i społecznej analizy sieciowej udowodniły, że społeczeństwo Litwy Sowieckiej pod względem społecznym, kulturalnym, systemu wartości było o wiele bardziej zróżnicowane, niż to pokazują badania prowadzone głównie z wykorzystaniem materiałów archiwalnych i na podstawie teoretyczno-ideologicznych przesłanek paradygmatu totalitarnej sowietologii. Kolejnym ważnym aspektem przeprowadzonych badań jest zwycięstwo naukowców w wyścigu z czasem: stworzenie unikatowego archiwum oral history, w którym zostały zarejestrowane bezcenne relacje o późnym okresie sowieckim, Sąjūdisie i pierwszych latach niepodległości Litwy.

\section{Poszukiwanie miejsca człowieka w historii i miejsca historii w życiu człowieka}

W latach 2007-2013 także autor niniejszego artykułu wykorzystał w swoich badaniach metodę oral history. Podczas realizacji projektu zostały nagrane wielogodzinne wywiady z historykiem Edvardasem Gudavičiusem, artystą Petrasem Repšysem i reżyserem filmowym Almantasem Grikevičiusem. Prywatne i artystyczne biografie tych osób (obejmujące czasy międzywojenne, sowieckie i postsowieckie) łączy nieustające zainteresowanie historią. Profesor E. Gudavičius jest uważany za jednego z najwybitniejszych historyków litewskich drugiej połowy XX wieku, P. Repšys jest określany przez historyków sztuki jako „najbardziej historyczny artysta litewski”, a A. Grikevičius w swoich filmach, tworzonych w czasach sowieckich, stale powraca do tematów $\mathrm{z}$ historii Litwy. Dzięki metodzie oral history utrwalone zostały $\mathrm{w}$ formie wywiadów, a później książek, trzy biografie wybitnych osobowości (Švedas, 2010, 2013; Kaminskaitė-Jančorienè \& Švedas, 2013). Podczas prowadzenia badań oral history nad zagadnieniem miejsca człowieka w historii i odczuwania historii przez człowieka, największą uwagę zwrócono na trzy kwestie:

a. Jak skomplikowana dwudziestowieczna historia państwa i społeczeństwa litewskiego, konkretne wydarzenia i procesy wpłynęły na rozwój osobowości oraz osiągnięcie dojrzałości (historyka, artysty, reżysera)?

b. W jaki sposób osobiste doświadczenie zetknięcia się z „niebezpieczną historią”, zdecydowało o zainteresowaniu przeszłością państwa i narodu litewskiego?

Pauliusa Subačiusa, w których poza różnymi komplementami pod adresem autorów badań, pojawiły się także liczne uwagi krytyczne związane z metodami badawczymi i ich możliwościami opisu obrazu społeczeństwa Litwy Sowieckiej. W tym samym numerze „Knygų aidai” została wydrukowana także odpowiedź inicjatorek projektu, kierowniczek zespołu badawczego Ainè Ramonaitė i Jūratė Kavaliauskaitė „Atsakymas į pastabas”. Jeszcze jedna bardzo poważna, zasługująca na uwagę, recenzja monografii zbiorowej Sajūdžio ištakų beieškant została przygotowana przez Neringę Klumbytè i wydrukowana w anglojęzycznym piśmie „Lithuanian Historical Studies” (Klumbytė, 2014). 
c. Jak konkretna osoba w okresie sowieckim zdołała przekuć swoje zainteresowanie historią w potężny wysiłek na rzecz (re)konstruowania przeszłości w sferze nauki, sztuki i kinematografii?

Żywa reakcja czytelników na historie życia trzech wybitnych osobowości - historyka, artysty plastyka i reżysera filmowego - pozwala sądzić, że zamysł autora badań, by wykorzystać formę dialogu do rozważania złożonych kwestii z przeszłości, sprawdził się i tym samym pobudził proces obiegu idei między historiografią a społeczeństwem, który, jak pokazuje doświadczenie, przebiega bardzo wolno ${ }^{17}$.

\section{Analiza pola literackiego Litwy Sowieckiej}

Kolejnym ważnym krokiem w kierunku popularyzacji oral history, rozszerzającym możliwości jej stosowania, były badania pola literackiego Litwy Sowieckiej (pojęcie wykorzystywane w badaniach za Pierre'em Bourdieu), które zrealizowali w latach 2012-2014 współpracownicy Litewskiego Instytutu Literatury i Folkloru (Kmita, 2015). Podczas badań przeprowadzono wywiady z 65 respondentami. Ich celem było wyjaśnienie: związków panujących między uczestnikami sowieckiego pola literackiego; zasad funkcjonowania mechanizmów władzy; emocji związanych z hierarchią uczestników pola; tego, jak wyglądały hierarchie z perspektywy prywatnej, nieoficjalnej i osobistej. Ogromne zainteresowanie społeczne rezultatami ${ }^{18}$ tego projektu pozwala twierdzić, że wydane w wersji książkowej oraz opublikowane na stronie Litewskiego Instytutu Literatury i Folkloru dwadzieścia dwa wywiady dopiero rozpoczynają swoje życie jako źródło historii socjokulturowej okresu sowieckiego ${ }^{19}$.

\section{E. Próba refleksji metodologicznej i teoretycznej}

Pierwszą próbą zainicjowania dyskusji o problemach metodologicznych i teoretycznych, z którymi muszą się zmierzyć przedstawiciele oral history, była międzynarodowa konferencja na Uniwersytecie Wileńskim „Sovietinè praeitis posovietinejje dabartyje metu" (Sowiecka przeszłość w postsowieckiej współczesności, 6-7 września 2012 roku). Wygłoszone podczas niej referaty badaczy z Rosji, krajów bałtyckich i Europy Centralnej, wykorzystujących w swej pracy metodę oral history, po czterech latach zostały wydane w tomie pod tym samym tytułem (Ilic \& Leinarte, 2016).

17 Najnowszą publikacją autora wymienionych wyżej prac z dziedziny oral history jest historia życia ocalałej z Holocaustu litewskiej Żydówki, znanej intelektualistki Ireny Veisaitè (Švedas, 2016).

${ }_{18} \mathrm{Na}$ Międzynarodowych Targach Książki w Wilnie w lutym 2015 roku prezentacja książki Nevienareikšmès situacijos zgromadziła najliczniejszą grupę czytelników. Jej zapis znalazł się na stronie internetowej telewizji i radia litewskiego w zakładce „mediateka”.

19 Wywiady te można znaleźć na stronie: http://www.llti.lt/lt/literaturos_laukas_sovietmeciu. Recenzje publikacji: Šulcè, 2015; Švedas, 2015. 
Refleksja akademicka dotycząca oral history jako metody badawczej, jej mocnych i słabych stron, ponownie wróciła dzięki zainicjowaniu przez grupę badaczy projektu Sovietmetis kaip sakytines istorijos objektas: atminties (re)konstravimo galimybes ir ypatumai (Okres sowiecki jako obiekt historii mówionej: możliwości i specyfika (re)konstruowania pamięci). Przeprowadzone badania miały na celu analizę i ocenę przesłanek i metod, które są wykorzystywane podczas tworzenia źródeł historii mówionej okresu sowieckiego na Litwie i na Łotwie. Aby osiągnąć zaplanowany cel, nie tylko studiowano różnorodną literaturę metodyczną i publikacje powstałe w wyniku konkretnych badań historii mówionej, ale także przeprowadzone w 2017 roku wywiady z siedmioma badaczami epoki Litwy Sowieckiej, wykorzystującymi w swej pracy naukowej metodę oral history. Jednym z rezultatów omawianego projektu stała się książka metodologiczna Sakytine istorijai kaip sovietmečio tyrimo metodas (Historia mówiona jako metoda badawcza okresu sowieckiego) (Vinogradnaite, Kavaliauskaite, Ramonaité, Ulinskaitè, \& Kukulskytė, 2018). W publikacji największą uwagę skupiono na czterech pytaniach, które można określić jako elementarz badacza historii mówionej: Co to jest historia mówiona jako model badawczy? Jak zorganizować wywiad historii mówionej? Jak zarchiwizować zebrany materiał? Jak używać metody historii mówionej zgodnie z zasadami etyki?

Są to oczywiście jedynie pierwsze kroki w procesie dyskusji nad głównymi zagadnieniami. Niewątpliwie, po zwróceniu się w kierunku zagadnień metodologii historii mówionej, litewscy naukowcy będą musieli także wkroczyć w sferę intensywnej refleksji teoretycznej, w której oral history daje możliwość wielostronnego współdziałania $\mathrm{z}$ historią i pamięcią, otwiera nowe perspektywy działania pamięci indywidualnej i zbiorowej, ma moc przemawiania w imieniu wspólnot, którym odebrano głos, pozwala społeczeństwu lepiej zrozumieć praktyczne znaczenie przeszłości dla teraźniejszości.

Wiadomo, że w tym przypadku nie można zapominać o specyficznej sytuacji naukowców regionu Europy Środkowo-Wschodniej, do którego należy Litwa. Jakiej historii potrzebuje ten region i jakie są szanse historii mówionej? - takie pytanie sformułował w 2010 roku Michał Kierzkowski (Kierzkowski, 2010), wymieniając kilka sfer, w których oral history w społeczeństwach postkomunistycznych ma możliwość zdziałania rzeczy ważnych, m.in. takich, jak: wzbogacenie pamięci społecznej o nowe narracje, edukacja historyczna, możliwość usłyszenia i zrozumienia Innego w historii, zaktualizowanie doświadczenia ludzi żyjących w przeszłości dla współczesności i dzisiejszego społeczeństwa. Oczywiście celne spostrzeżenia Michała Kierzkowskiego doskonale pasują do sytuacji Litwy. Potwierdza to także rozwijająca się w litewskiej humanistyce tradycja oral history. 


\section{Wnioski}

1. Metoda oral history jest wykorzystywana przez litewskich humanistów do gromadzenia informacji o różnych zdarzeniach, wydarzeniach, procesach i osobach z okresu sowieckiego i wczesnego postsowieckiego. Najczęściej wybierają tę metodę badacze młodego pokolenia zajmujący się problematyką sowiecką w swoich rozprawach doktorskich. Zazwyczaj pamięć staje się obiektem badań w sytuacji braku dokumentów archiwalnych, w celu uzyskania unikatowej jakościowo, niespotykanej w żadnych innych źródłach historycznych, informacji. Proces rozwoju tradycji oral history na Litwie (podobnie jak i w innych krajach postsowieckich) w istotny sposób różni się od procesów, które dokonały się w historiografii zachodnioeuropejskiej.

2. Najważniejszymi wyzwaniami, z którymi stykają się przedstawiciele litewskich nauk humanistycznych pracujący w sferze oral history są: panujące przez długi czas, nieprzychylne tym badaniom wartościowanie wytworów działalności naukowej; braki w refleksji teoretycznej, utrudniające naukowcom korzystającym $\mathrm{z}$ tej metody wykonanie następnego kroku: od zbierania faktów do rozwiązywania złożonych problemów badawczych $\mathrm{z}$ dziedziny historii i pamięci.

3. Poza wymienionymi wyżej wyzwaniami w ukształtowanej w litewskiej humanistyce XXI wieku tradycji badań oral history można dostrzec kilka znaczących obszarów badań: badania zmian tożsamości kobiet obejmujące lata 40. -70. XX wieku; badania wpływu sieci społecznych uformowanych w późnym okresie sowieckim na genezę powstania Sąjūdisu; badania opowieści biograficznych wybitnych postaci litewskiego życia naukowego i artystycznego w kontekście procesu poszukiwania miejsca człowieka w historii i miejsca historii w życiu człowieka; badanie pola literackiego sowieckiej literatury litewskiej; próby refleksji metodologicznej, dążące do ustalenia zasad pracy w sferze oral history.

4. Chociaż litewskie badania $\mathrm{z}$ dziedziny oral history dopiero się rozwijają, to jednak istniejący już dorobek pozwala sądzić, że naukowcy korzystający z tej metody potrafili wzbogacić historiografię litewską o nowe tematy, a pamięć społeczeństwa o nowe narracje. W ten sposób przyczynili się do rozwiązania złożonych problemów naukowych (np. badania genezy Sąjūdisu) oraz sprawili, że doświadczenie ludzi żyjących w XX wieku stało się aktualne także dla współczesnego społeczeństwa Republiki Litewskiej.

Tłum. Tomasz Błaszczak i Małgorzata Kasner

\section{Bibliografia}

Aleksynas, K., \& Giliasevičiene, D. (Red.). (2012). Homo narrans: Folklorine atmintis iš arti: Kolektyvine monografija. Vilnius: Lietuvių literatūros ir tautosakos institutas. 
Baločkaitè, R. (2009). Antrosios lyties liudijimai sovietmečio tema. Šiaurés Aténai, 2009(1), 9.

Dobriakov, J. (2014). 90-uosius Lietuvoje reikia sukurti. Literatūra ir menas, 2014(21), 3-5.

Grybkauskas, S. (2007). Pramonès valdymas sovietineje Lietuvoje 1965-1985 m.: Itampos ir konfliktai (Praca doktorska). Vytauto Didžiojo universitetas, Kaunas.

Hobsbawm, E. (1999). Wiek skrajności: Spojrzenie na krótkie XX stulecie 1914-1991 (M. Król \& J. Kalinowska-Król, Tłum.). Kraków: Politeja.

Ilic, M., \& Leinarte, D. (Red.). (2016). The Soviet past in the post-socialist present: Methodology and ethics in Russian, Baltic and Central European oral history and memory studies. New York, NY: Routledge.

Ivanauskas, V. (2008). Lietuviškoji nomenklatūra biurokratinèje sistemoje: Tarp stagnacijos ir dinamikos (1970-1988) (Praca doktorska). Vilniaus universitetas, Vilnius.

Jurkutè, M. (2016). Lietuvos partizanu karo atmintis: Sovietinis, vietinis ir išeivijos pasakojimai (Praca doktorska). Vilniaus universitetas, Vilnius.

Kałwa, D. (2010). Historia mówiona w krajach postkomunistycznych: Rekonesans. Kultura i Historia, 2010(18). Pobrano 2 października 2018, z http://www.kulturaihistoria.umcs. lublin.pl/archives/1887

Kaminskaitė-Jančorienè, L., \& Švedas, A. (2013). Epizodai paskutiniam filmui: Režisierius Almantas Grikevičius. Vilnius: Vaga.

Kavaliauskaitè, J., \& Ramonaitè, A. (Red.). (2011). Sajūdžio ištaku beieškant: Nepaklusniųju tinklaveikos galia. Vilnius: Baltos lankos.

Kierzkowski, M. (2010). Jakiej historii potrzebuje Europa Środkowo-Wschodnia? Szanse historii mówionej. Porównania, 2010(7), 43-55.

Klumbys, V. (2009). Lietuvos kultūrinio elito elgsenos modeliai sovietmečiu (Praca doktorska). Vilniaus universitetas, Vilnius.

Klumbytè, N. (2014). [Recenzja monografii „Sąjūdžio ištakų beieškant” J. Kavaliauskaitė, A. Ramonaitè]. Lithuanian Historical Studies, 2014(4), 221-225.

Kmita, R. (Red.). (2015). Nevienareikšmès situacijos: Pokalbiai apie sovietmečio literatūros lauką. Vilnius: Lietuvių literatūros ir tautosakos institutas.

Kmita, R. (2016). Pietinia kronikas: Popromanas. Vilnius: Tyto Alba.

Marcinkevičienè, D. (2007). Prijaukintos kasdienybès. 1945-1970 metai: Biografiniai Lietuvos motery interviu. Vilnius: Vilniaus universiteto leidykla.

Marcinkevičienè, D. (2010). Adopting and remembering Soviet reality: Life stories of Lithuanian women, 1945-1970. Amsterdam: Rodopi.

Ramonaitè, A. (Red.). (2015). Nematoma sovietmečio visuomenè. Vilnius: Naujasis Židinys - Aidai.

Ramonaitè, A., Kavaliauskaitė, J., \& Klumbys, V. (Red.). (2015). Kažkas tokio labai tikro: Nepaklusniosios sovietmečio visuomenès istorijos: Sakytinès istorijos šaltinių rinkinys. Vilnius: Aukso žuvys.

Šapoka, K. (2018). Pušis, kuri juokèsi. Vilnius: Kitos knygos.

Šukys, A. (2012). Intelektualų alternatyvi veikla sovietu Lietuvoje 1956-1988 (Praca doktorska). Vytauto Didžiojo universitetas, Kaunas. 
Šulcè, S. (2015). Sakytinè istorija ir sovietmečio literatūros laukas. Knygu aidai, 2015(1), 1-4. Švedas, A. (2008). Visa istorija yra gyvenimas: 12 sakytinès istorijos epizodų: Edvardą Gudavičiu kalbina Aurimas Švedas. Vilnius: Aidai.

Švedas, A. (2010). Sakytinès istorijos galimybès sovietmečio ir posovietinės epochos tyrimuose (atminties kultūros ir istorijos politikos problematikos aspektas). Lietuvos istorijos studijos, 2010(26), 148-161.

Švedas, A. (2013). Piešimas buvo tarsi durys: Petrą Repši kalbina Aurimas Švedas. Vilnius: Aidai.

Švedas, A. (2015). Pokalbiai kaip patirčių atverties ir prasmių kūrimo laukas. Colloquia, 2015(34), 190-196.

Švedas, A. (2016). Irena Veisaitè: Gyvenimas turètų būti skaidrus. Vilnius: Aukso žuvys.

Thomson, A. (1998). Fifty years on: An international perspective on oral history. The Journal of American History, 85(2), 581-595. https://doi.org/10.2307/2567753

Thomson, A. (2007). Four paradigm transformations in oral history. The Oral History Review, 34(1), 49-70. https://doi.org/10.1525/ohr.2007.34.1.49

Tornau, Ū. (2016). Oficialieji ir kasdieniai sovietinio Vilniaus erdves naratyvai: Lukiškiu mokslo kvartalas (Praca doktorska). Vilniaus dailès akademija, Vilnius.

Vaiseta, T. (2012). Du radikalieji klausimai: Po tarptautinès konferencijos apie sakytinès istorijos taikymą sovietmečiui tirti. Naujasis Židinys - Aidai, 2012(6), 415-417.

Vinogradnaitè, I., Kavaliauskaitė, J., Ramonaitė, A., Ulinskaitė, J., \& Kukulskytė, R. (2018). Sakytine istorija kaip sovietmečio tyrimo metodas. Vilnius: Vilniaus universiteto leidykla.

Žilinskienè, L., Leinartė, D., Kraniauskienė, S., Šutinienė, I., \& Gečienė, I. (Red.). (2014). Sovietmečio atmintis gyvenimo istorijose: Monografija. Vilnius: Vilniaus universiteto leidykla.

\section{Formy dialogu pamięci i historii w humanistyce litewskiej po roku 1990 (wykorzystanie metody oral history)}

\section{Streszczenie}

Przedmiotem artykułu jest ukształtowana w litewskiej humanistyce niepodległej Republiki Litewskiej tradycja badań z wykorzystaniem metody historii mówionej (ang. oral history). Podczas pisania tego artykułu poszukiwano odpowiedzi na następujące pytania: W jaki sposób na przełomie XX i XXI wieku litewscy przedstawiciele nauk humanistycznych korzystają z metody badawczej oral history oraz wobec jakich wyzwań stają? Jakie zagadnienia badawcze były, są i będą rozwiązane w najbliższej przyszłości dzięki wykorzystaniu tej metody? Jakie teksty wykorzystujące metodę oral history należy uznać za najważniejsze i o największym potencjale w kontekście procesów zachodzących w litewskiej humanistyce? Artykuł składa się z dwóch części. 
W pierwszej omówiono różnego rodzaju wyzwania, przed którymi stają badacze litewscy wykorzystujący oral history jako główne narzędzie badawcze. W drugiej części tekstu skupiono się na prezentacji i omówieniu konkretnych przykładów zakończonych sukcesem badań z wykorzystaniem metody wywiadu oraz sposobów rozwiązywania pojawiających się problemów.

Słowa kluczowe: historia mówiona - oral history; litewska nauka humanistyczna; historiografia litewska; pamięć; przełom XX i XXI wieku

\title{
Forms of dialogue between memory and history in the Lithuanian humanities after 1990: On the use of oral history
}

\begin{abstract}
This article is devoted to the tradition of research using the method of oral history which has developed in the Lithuanian humanities since the country's independence. It attempts to explain how Lithuanian scholars have employed the method and what challenges they face using it; what research problems they have resolved as a result and what they still hope to achieve in the near future; what studies based on the method of oral history should be considered the most important and display the highest potential in the context of developments in the Lithuanian humanities. The first part of the article discusses various challenges faced by Lithuanian scholars who rely on oral history as their main research tool. In the second part the focus is on the presentation of particular cases of successful studies employing the interview method; it also shows how scholars working on these projects addressed different problems which they encountered.
\end{abstract}

Keywords: oral history; Lithuanian humanities; Lithuanian historiography; memory; turn of the 21st century

Doc. Dr Aurimas Švedas, Associate Professor of History at the Faculty of History, Vilnius University; PhD dissertation - 2006, Vilnius University. Author of three books and co-author of six; editor of three books and author of about fifty scholarly 
articles, essays and reviews. Research interests: oral history, historical politics, history of Lithuanian historiography, cultural memory.

Bibliography (selected): Piešimas buvo tarsi durys: Petrą Repši kalbina Aurimas Švedas [Painting was like a door: Aurimas Švedas talks with Petras Repšys], Vilnius 2013; (with Lina Kaminskaitė-Jančorienè), Epizodai paskutiniam filmui: Režisierius Almantas Grikevičius [Episodes for a final film: Film director Almantas Grikevičius], Vilnius 2013; In the captivity of the matrix: Soviet Lithuanian historiography, 1944-1985, Amsterdam/New York 2014; Irena Veisaitė: Gyvenimas turètu büti skaidrus [Irena Veisaitè: Life should be transparent], Vilnius 2016.

Correspondence: Aurimas Švedas, Faculty of History, Vilnius University, e-mail: aurimas. svedas@if.vu.It

Support of the work: The study was conducted at the author's own expense.

Competing interests: No competing interests have been declared. 